\title{
"Technology Brings Learning to Life": Planning Writing Opportunities through Multimodal and Digital Resources
}

\author{
CAROL DOYLE-JONES \\ Niagara University
}

\begin{abstract}
This paper illustrates how participating elementary teachers plan their literacy-based curriculum and create learning opportunities for writing through multimodal resources and digital technology tools in their classrooms. A theoretical lens of New Literacies (Coiro et al., 2008; Leu et al., 2013) guides this qualitative study. Through comprehensive interviews and an analysis of activity resources and digital tools, how teachers plan and design writing curriculum with a multimodal focus and create opportunities for collaboration and enhancing authorship are discussed.
\end{abstract}

\section{Introduction}

Am I going to get you to sit down with a piece of paper and write a re-count, or am I going to get you to take out your iPad and find a digital photo, immerse yourself into music, and create a whole movie that re-counts your adventure? Let's do that now. (George, grade 6 teacher and literacy coach)

This study illustrates how participating elementary teachers plan their literacybased curriculum and create learning opportunities for writing through multimodal and digital resources and tools in their classrooms. This research also reflects upon how educators are to implement quality digital-based literacy practices in their classrooms, considering how quickly digital technologies evolve (Coiro, Knobel, Lankshear, \& Leu, 2008). These teachers, such as George, actively search and explore digital sites, technologies, resources, and devices to use in their planning and in their classrooms. Based within a larger study of teachers' perceptions of teaching strengths, their understandings of literacy, and the types of environments that support teachers addressing the challenges of teaching with multimodal practices, this paper focuses on how ten participating teachers plan their writing curriculum and "effectively scaffold new literacies learning" (Lapp, Moss, \& Rowsell, 2012, p. 376). The overarching question that guides this paper is as follows: How do participating literacy teachers plan writing curricula utilizing digital technologies for multimodal texts in their classrooms?

Implementing quality digitally-based literacy practices in the classroom is a challenge undertaken by the participating teachers in this research study. These literacy practices, a combination of classroom, digitally-based literacy events and contexts, are based in multimodal teaching and learning. Through work done by researchers and educators of multimodalities, multimodal teaching principles have been constructed. 
These principles include making meaning by teaching and learning with multiple modes, utilizing digital technologies as tools and resources, providing choice in multimodal projects, and integrating texts from students' lives outside of school. Teachers who follow these principles of multimodal teaching often engage students in inquiries using technology. I recently noticed a young student reading J. K. Rowling's (2000) Harry Potter and the Philosopher's Stone, and answering one-dimensional questions for each chapter that the teacher had assigned for homework. While we discussed some of the characters in the book, he asked me if I thought the snake from the zoo was also Nagini, Voldemort's horcrux snake which appears later in the series. I thought this was a thoughtful question and we searched for the answer on Rowling's Pottermore website but could not uncover a solution. Since we discovered J. K. Rowling does not answer emails, we decided to type a letter to the author via her publisher. Through this exercise not only did I find out how deeply the student had read this book, but we also embarked on an authentic writing event. This type of writing event also bridges print and digital texts and tools through a teaching and learning opportunity. As Edwards-Groves (2012) found, new pedagogical and literacy practices "have enabled students in their everyday life and in their classrooms to become multimodal designers of text, as writing now requires multimodality, creativity, and technological and technical creativity" (p. 99). There are a multitude of benefits for implementing digital technologies in the classroom through multimodal teaching practices. As Ria, a grade 7/8 teacher in this study, realized, she often turns to technology and media first when planning her curricula, as she discovered that in her classroom "technology brings learning to life."

\section{Literature Review}

How teachers understand literacy today is reflected in how they plan their writing curriculum, whether it is to authentically incorporate digital technology, develop multimodal assignments, or find various ways to engage their students in text-based projects. Karchmer-Klein and Shinas (2012) note that "teachers must recognize the new literacy demands of the $21^{\text {st }}$ century and, most important, must transform their programs to meet these demands with timely literacy instruction" (p. 289). For example, Jeff, a grade two teacher contributing to Kist, Doyle, Hayes, Horwitz \& Kuzior's (2010) research, used Twitter with his grade two class to encourage parents to ask detailed questions about their children's day at school. Jeff shared: "We are teaching our students to communicate, collaborate, and use technological tools to create learning networks that will enable them to become more successful learners in the $21^{\text {st }}$ century" (p. 65). This statement echoes Kress (1997), who found that if "language is seen as a dynamic, organic, fluid phenomenon, constantly shaped and re-shaped by those who speak and write it every day in accordance with their needs and wishes, then the educational task becomes different" (p. 151). These educational activities that teachers create must have a foundation not only in following the prescribed curriculum, but also in evolving and dynamic social interactions (Bomer, Zoch, David, \& Ok, 2010; Edwards-Groves, 2011; Hutchison, Beschorner, \& Schmidt-Crawford, 2012; Lenters, 2014; Mills, 2010). Then, for instance, teachers can be encouraged to learn "more about the diversity of young children's experience of digital writing in out-of-school contexts in order to better understand their literacy capital" (Merchant, 2008, p. 769), thereby incorporating digital technologies into authentic meaning-making curriculum. 
While this study focuses on teachers and their curricula planning with texts, creating engaging teaching opportunities is intertwined with student learning. As Edwards-Groves (2012) found, new pedagogical and literacy practices "have enabled students in their everyday life and in their classrooms to become multimodal designers of text, as writing now requires multimodality, creativity, and technological and technical creativity" (p. 99). Teachers who utilize multimodal methods often organize their curriculum activities so students engage with literacy curricula in a variety of ways: sometimes through sharing their out-of-school experiences (Fantozzi, Johnson, \& Scherfen, 2017; Hull \& Schultz, 2002), perhaps exploring cross-curricular writing in multimodal ways (Cook \& Kirchoff, 2017; Jewitt, 2005), 'reading' the art in picture books in order to create a response (Martens, P., Martens, R., Doyle, Loomis, \& Aghalarov, 2012), designing digital storytelling products (Hull \& Katz, 2006; ShelbyCaffey, Úbéda, \& Jenkins, 2014), or playing with and integrating digital technology (Hutchinson et al., 2012; Ware, 2006). These instances in the classroom, when teachers and learners expand what it means to be literate, can create spaces "for the blending of traditional and new literacy practices" (Shelby-Caffey et al., 2014, p. 199). While learning and teaching do not always have to utilize technology, I wonder how often digital technology winds its way into the curriculum of these participating teachers to create engaging, authentic literacy activities in their classrooms.

\section{Theoretical Perspectives}

While the theoretical underpinning of this research lies in New Literacies theory, related theories, such as multiliteracies (New London Group, 1996, 2000; Cope \& Kalantzis, 2009), also provide the support beams upon which the larger study was built. Identified with "knowing how and when to make wise decisions about which technologies and which forms and functions of literacy most support one's purposes" (Coiro et al., 2008, p. 5), work in New Literacies illustrates how and why digital technologies are utilized in the classroom. New Literacies helps explore specific changes in textual practices through multimodal means and how these communication changes are mediated. In this New Literacies perspective, four characteristics are evident: new information and communication technologies "bring new potentials to literacy tasks"; participation in the global community requires "instructional equity" in terms of digital technologies; change is an important aspect of technology, therefore, change is essential for literacy as well; and "new literacies are multiple, multimodal, and multifaceted" (Coiro et al., p. 14). This group of researchers continues to identify more principles to add to the characteristics stated above: the need to encompass critical literacies while utilizing "new forms of strategic knowledge" and new social practices; and, while teachers' roles may change in the classroom, their importance as educators does not (Leu, Kinzer, Coiro, Castek, \& Henry, 2013, p. 1158). Furthermore, while “the Internet is this generation's defining technology for literacy and learning", new literacies understandings are necessary "to fully access their potential" (Leu, et al., 2013, p. 1158). Knobel and Lankshear (2007) further describe New Literacies pedagogies as a view of literacy as fluid, collaborative, and less centred on individual authorship in order to provide space for various types of learning and collaboration. They call for the integration of technology in classrooms, particularly Web 2.0 applications such as blogs, wikis, and other socially and dynamically interactive digital tools. As teachers utilize digital 
applications in their classrooms they prompt participation from their students, not just in the form of using a new digital technology, but in new ways of forming learning communities and allowing teachers and the students to facilitate learning in different roles.

New Literacies takes a comprehensive approach to understanding literacy and goes beyond examining the influence of technology and media on communication; it looks at the very nature of what constitutes authorship and social relationships in collaborative writing practices. For example, McClenaghan (2013) found that integrating a Moodle, a Virtual Learning Environment, into his literacy and math programs encouraged his students to write more, both collaboratively and individually, as the students saw their work as authentic and purposeful. The constant changes in our classrooms provide an opportunity for teachers to "encourage students to produce texts that matter to them in different formats and for different audiences and purposes and that allow them to draw on and extend their range of semiotic resources" (Janks, 2010, p. 156). Multimodality is an important concept, also found within New Literacies, in understanding how teachers are often shifting from teaching writing using traditional print to using textual artefacts and/or digital resources. Graham and Benson (2010) demonstrate how multimodal pedagogy focuses "on process rather than product alone" (p. 93). Multimodal planning focuses more on the process in order to provide multiple opportunities for students to learn with and through digital technologies, and requires an effort by teachers to explore the tools and capabilities of digital technologies. A New Literacies perspective helps reveal how the participating teachers in this study plan and create learning opportunities in their literacy classrooms, and what designs and resources are particularly helpful in their everyday practices.

\section{Research Design}

As learning spaces are ever evolving and flexible, incorporating qualitative methods (Creswell, 2007; Schultz, 2006) provided opportunities to gather information about the evolution of participating teachers' identities and practices, about the supports and challenges that influence and have influenced their literacy teaching, particularly in the area of writing, and about their professional goals for future teaching. In order to collect "data in a natural setting sensitive to the people and places under study" (Kendall, 2008, p. 37), teachers were interviewed in a natural setting for their planning purposes, often in cafés, their homes, or their schools after their students had gone home. Face-toface, semi-structured interviews (Kendall, 2008) were conducted with participating literacy teachers from central Canada. Interestingly, 4 of the pairs of teachers asked to be interviewed together as they always co-planned, and sometimes co-taught. Teachers brought an example of a lesson or activity that illustrated their use of digital technologies to the first interview, which was approximately 1 hour in length, usually followed within days or weeks by a 30-60 minute interview. In the second interview, teachers answered any additional questions, and clarified any parts of their transcriptions, that arose as the data analysis process began. Examples of some of the interview questions from the Planning Multimodally with Digital Technology set are as follows:

1. During a typical week, how do you use digital technology and media in your classroom? 
2. Please describe a successful lesson or activity where you used digital technology. (You can use the curriculum unit or activity that you believe relates to multimodal resources and teaching and digital technology that you brought with you.)

3. How did you develop that particular activity/lesson plan?

4. What kind of support have you had in using digital technology in your classroom?

5. Do you have a support network (i.e. at school or at home) to help you with technology in the classroom?

The teachers' narratives were supplemented with commercial and online resources, digital tools, together with the curriculum resources and provincial Ministry of Education documents that the teachers used to plan the teaching and learning activities.

In order to describe the social interactions and situations that teachers perceived allowed them to reflect on their own teaching practice with literacy curriculum planning and digital technologies, a grounded theory approach (Charmaz, 2005; Corbin \& Strauss, 2008; Glaser \& Strauss, 1967) was utilized to conduct the data analysis. Categories, such as multimodal writing, were generated from coding the data, and that evidence or the selective quotes from the data were used to illustrate the themes (Corbin \& Strauss, 2008). By comparing and contrasting the data, interrelationships among the categories led to the development of themes. Related concepts, such as access and constraints of planning multimodally, thus developed as the concept became saturated. Data memos, interview notes, and journaling provided further space for reflections regarding the data and how to convey meaning about the emerging concepts. This approach provided space for participants' voices to include their related experiences and further the conversation by sharing related ideas and comments. This study focuses on insights provided from the participating teachers' perspectives while they discussed what happens in their other workspace, the space where they plan lessons, activities, and units, to discover what helps them be effective teachers of writing in their classrooms.

\section{Participating Teachers}

While 15 teachers participated in the main project, and all discussed multimodal elements of teaching writing, only 10 teachers consistently spoke of writing with depth. These 10 teachers' voices are the ones we hear in this paper. The participating teachers are all elementary teachers and, at the time of the interviews, had classroom and school board experiences ranging from 4 to 26 years. While most of the teachers had taught in a variety of grades, at the time of this study they taught in grades 3 to 8 , in rural and urban centers across Ontario. As the teachers reflected on their own teaching practices in order to make changes in their pedagogy, teacher biographies were created to help develop the teachers' stories. All names are pseudonyms.

Cassidy and Claire were both teaching grade 3 in different urban schools and had 6 years of classroom experience each. Claire found that her public school's team teaching approach not only benefits the teachers but the students as well. Cassidy believes her students are "little sponges and they need [teacher] to be passionate and caring and enthusiastic about what they're doing." Teaching grades 3/4, Roxanne had a Master's degree in second language learning and has been a second language teacher for 13 years, while Sheba has taught every grade, including special education, during her 25 years as 
an educator. Roxanne shared her advice about teaching: "You really have to look at the kids in front of you and decide what's the best way to teach. You have to bring learning to life in own your teaching!"

Leela and Daphne have been teaching partners in grades 5 and 6 for the past 12 years in an urban school. They both described their pedagogy as opportunities to take chances with team teaching and digital technologies in their classrooms. In describing her understanding of literacy, Daphne shared how literacy is about "making sense and meaning of content in various contexts, and what you do with that knowledge." Daphne was excited to describe how "the new literacies out there are not just words on a page. It's communication, text, audio, hyperlinks, visuals, and the interaction between the different aspects. It's a media explosion of how we're taking information and making sense of it." Leela and Daphne both have graduate degrees in education and were continually taking university-level courses and/or presenting aspects of their practice in school board-sponsored workshops. Dona and Ted were also teaching partners, in grade 8, in a small, rural school. Dona, also a French and Special Education teacher, had been teaching for eight years, while Ted had been teaching for five years as the DI (Differentiated Instruction) school coach. Ted and Dona also often practiced with digital tools and resources, and then shared their new knowledge with their school staff.

Teaching in urban schools, Ria and George were literacy coaches for their respective school boards, and organized co-curricular activities with their students. Ria, a grade 8 teacher, recalled how, as a new teacher:

I fell into the trap of teaching how I was taught. I remember how during my first year of teaching I was photocopying packages for my kids for March Break and another teacher came in and asked what I was doing. When she asked what I was doing during the Break, she said, 'Don't you think the kids want to hang out too?' That changed my whole perspective and I started to see how I could teach differently.

George, a grade 6 teacher and literacy coach, noted that "I challenge teachers and they challenge me."

\section{Discussing the Findings}

The participating teachers, when asked about planning their literacy curriculum, often steered the conversation towards writing. While discussing their educational histories, all the teachers shared that the way writing is now taught is vastly different from their own school experiences. Daphne said that when she was a student "there was no moving forward, only maybe you would do better on the next piece. The learning gaps just became bigger. Whereas now we give many opportunities for dialogue and taking risks, to reflect upon and build upon the feedback, and that there's value in applying the feedback." Daphne also found that teaching writing now incorporates a safer space to share work because of the small group instruction, many opportunities for students to reflect on their work, and for teachers to provide constructive descriptive feedback. Claire concurred, explaining that a model of comprehensive, or balanced literacy, is now found in her district's schools: 
That's where the gradual release of responsibility comes in: you watch while I do, and then you try it with someone else, and then you try it on your own. So that's the modelled practice, the guided work, the shared work, and then the independent piece. And you should be successful after I've given you multiple attempts.

Ultimately, in order to be successful, Leela shared that "you have to let the kids know that you care and that they have a voice. I think they need to know that you are invested in them... and that their words and what they're saying actually has a wider scope and meaning to the wider audience."

All the participating teachers utilized various digital tools to engage their students. Daphne shared how "you can know all the content curriculum and all the niches, but if you can't get the kids to stick around and engage then it doesn't matter." One way Daphne and Leela engaged their students, and themselves, was by incorporating technology into their curriculum. Daphne hoped that by "working with online tools in a responsible, respective manner, hopefully it carries over, translates, into their use of social media." In relation to engaging his students in his writing program, George came to a point in his teaching where he was asking himself:

I'm asking you to write but we have these powerful tools in front of us. If you bring in an iPad you should run with that. That's what you should be using instead of on a piece of paper. Why not use the technology to edit writing and create new modes of presenting your work? Technology is a powerful tool, let's use it!

These teachers explored digital technologies as resources for teaching writing and found that digital and multimodal tools helped create writing opportunities for meaningful writing. Three themes emerging from the data will be discussed in this section: planning and designing writing curriculum, planning multimodal writing with digital tools, and collaboration and authorship.

\section{Planning and Designing Writing Curriculum}

How do these teachers teach writing? As many of the lesson activities that the teachers shared were based in writing procedures, and while the teachers shared some of their favourite or most engaging activities, we were able to discuss the positive and negative elements of planning and designing effective writing curriculum. Ted said he often asks himself, "What are we writing for?" He found that "someone who is literate communicates well with other people, not just in terms of reading and writing, but in speaking and communicating too. We need to teach how to communicate to different audiences." Roxanne, for example, discussed the importance of supporting students to communicate their ideas during the writing process. She noted that she always integrated conferencing throughout the writing process because "their writing levels are so varied I have to be able to grab a group and work on any challenges." Roxanne described her integrated Social Studies and Language Arts unit on First Nations' peoples' lives, history, and legends, which took two months of class time to build. Roxanne modelled reading while using the Smartboard to project the First Nations' legends she was sharing. Then they created an anchor chart together about the components of a legend. After reading, modelling, and sharing legends, then, "we could work at writing our own legends. You 
have to really build it up before the writing piece because if you just pull it out of a hat it won't work. And then we did pre-writing activities, graphic organizers, pictures, some on the computers." Roxanne incorporated writing conferences and guided writing with legends in groups. Roxanne said, "They go through the process writing, all the drafts, and then they illustrate it. Then we share our writing with our reading buddies." Roxanne found that all the curriculum planning, going through the writing process, and integrating digital technology where needed, provided multiple opportunities for her students to become aware of themselves as writers.

Claire and George spoke about the positive and negative aspects of planning activities for procedural writing. To teach procedural writing to her grade 3 class, Claire utilized ideas found on Pinterest, her main 'go to' place for activity ideas for her classroom. To introduce this genre of writing to her students, Claire made popcorn in her classroom and, together, they wrote out the instructions. Claire "scribed what they said, had a little discussion and made a list" as a class. While the event had many starts and stops because the students kept remembering to add different steps, Claire found the exercise to be "such a visual [aid] for procedure [writing]. And the kids had fun. The point being that you have to be specific about what you are writing down. So, we fixed up our note, adding things in different colours, made the popcorn, and passed it out to share." After collaborating on this writing activity, Claire had her class do their own procedural writing project on blowing bubble gum. Inspired by ideas on her Pinterest board, the activity consisted of designed a face, blowing up a pink balloon and sticking it to the mouth, and then writing down the procedure of blowing a bubble. Together, these activities discovered through an online educational resource, provided opportunities for student writing.

George, on the other hand, spoke about how sometimes teaching writing can have a negative impact on students' learning if it is not done in an engaging way. As a literacy coach, George would often be asked to co-teach with classroom teachers or provide assistance with teaching strategies. During one of his class visits to a colleague in a different school he observed the intermediate students doing oral presentations based on a procedural writing activity about tying shoes:

So this boy got up and did one on how to tie his shoe. Step one... It was insulting to him and to everyone. I wondered what was going on here. The assignment wasn't really challenging. Why does he have to give an oral presentation on how to tie his shoe? [When George spoke with the teacher] I tried not to talk about the assignment like it was a waste of everyone's time. I talked about teaching something real, like doing a presentation on something we can actually learn from and about.

During our interview, George and I talked about how the teacher might not have known what else to do and how to counter disengagement. George believes that "there are important skills to learn. You can teach how to manage information and how to use it, plus what sources are being used. You can never underestimate the power of what kids can do, so don't insult what they can do. Ultimately though, don't get them to tie their shoe, and then tell you about it." George spoke about the importance of choice in writing programs and how topics can be engaging and individualized even when the skills being 
taught are the same for the whole class. Claire also shared how students "should have a chance to write what they want to write about. I don't care if you've got them writing a comic or writing a grocery list, they're still writing." Providing choices for students when they are learning to write, whether in the genre, method, or topic stage, vastly improves engagement between students and what they are writing.

Finally, providing different entry points for writing, often digitally, was a goal for all the teachers. Believing that writing was her weakness as a student, Cassidy was selfconscious with her own ability to teach writing, "I don't remember getting taught how to write properly. I've only been able to write well since I became a teacher really." Cassidy shared how she connects with struggling writers in her own classroom: "It's a struggle to teach writing too but you have to do it. Now I try different things and strategies with the kids, and how to connect with those one or two kids who don't get writing either." Sheba argued that communication is an integral part of the process of literacy as it "is being able to read, understand what you read, and apply it. Then, it's being able to express yourself through writing, clearly, so people can understand you. Next, it's being able to take all that reading and writing and share it orally." Sheba believed "that's what literacy is, being able to get your point across to other people." For these teachers, different entry points and writing topic choices were found to be defining elements in planning and designing writing curriculum.

\section{Planning Multimodal Writing Opportunities with Digital Tools}

With the affordances of technologies, the act of teaching writing has shifted. Leela hoped that "the introduction of different tools throughout the school year provides each of her students with an entry point into what they are trying to do. Each new project is a new chance." Leela and Daphne noted how, while using Wikispaces (unfortunately, this site has recently closed) and Web 2.0 tools in their classrooms, their virtual classroom was an "evolving textbook. It changes all the time because of what the students need. Then, there is also accountability and a release of responsibility too." For example, when their students asked to have access to the anchor charts and success criteria on their classroom walls, the two teachers discovered how to create side bars and on their wiki so "anything modelled or co-constructed in class is there online." They continually helped their students create spaces for learning opportunities though digital tools.

These participating teachers taught writing in a variety of ways. Ria, for example, created an activity to teach not only summarizing skills, but the importance of word choice, that would go beyond having students write "this happened and then that happened." First, Ria created a section on her Twitter account for her classroom and invited some of her educator friends to join. By using a poetry book about basketball, entitled Rimshots: Basketball Pix, Rolls, and Rhythms (Smith, 2000), she gave each group the same humorous poem called "Please Put Me in Coach". Only having 140 characters to summarize the poem, Ria "asked how we can summarize our thoughts through tweets. I tweeted the seven summaries from the seven groups of students to my friends, pulled up my twitter account on the projector, and we all talked about the summaries. They loved it!" Ria discovered that her students were not having the same trouble any more with summarizing. Then her teacher candidate, a pre-service student teacher, wanted to implement a novel-in-an-hour activity. They used the novel Crash by Spinelli (1996) and had groups of students tweet the summaries of each of the five chapters. "Again, they 
loved it," said Ria, as they also realized the necessity of summarizing and word choices. Together as a class, students and teacher critically analyzed the tweets to determine summary skills and to discuss the need in society for succinct, powerful word choices for communication purposes.

Claire and Daphne shared different ways of teaching writing elements through digital technologies. In order to teach how to use quotation marks, Claire used the pigeon stories by Mo Willems, such as Don't Let the Pigeon Drive the Bus (Willems, 2003), to illustrate how to incorporate dialogue. By reading and dissecting the stories, Claire found that her students were able to make connections to the dialogue in the picture books and their own work. Next, Claire integrated a digital comic-creator tool by teaching her students how to construct comics through Bitstrips. Based on their previous knowledge, Claire's students then created their own humourous comic strips, complete with speech bubbles to place their quotes. Claire said, "It was highly engaging. They told their story, disguised as a comic strip." Utilizing various multimodal tools provided opportunities for teaching and learning for these teachers. Daphne described how she had a student who just could not start projects, particularly writing activities. She said, "He could look at people's work and be excited about the project, but it didn't help him start." Then they discovered bubble.us, a site with a bubble-type graphic organizer. Daphne described "his writing as linear, mechanical, but at least he could start. Choice of tools is important." These particular teachers, whether they were within the first 5 years of teaching or they were close to retiring from the profession, made extra time to uncover new and useful digital tools. Sometimes these tools and resources were discovered through their professional networks (i.e. blogs, workshops, online teaching spaces) and often they were shared by their students and peers, creating a network of experts.

Continuously integrating digital technologies into his classroom, George wants to "continue to explore this amazing, unique way to produce information. I want to explore these powerful devices for reading, writing, speaking, viewing, and media literacy." George was not alone in this goal of exploration; all the teachers were passionate about how they could engage their students in multimodal writing opportunities.

\section{Collaboration and Authorship}

The teachers found that teaching writing while exploring digital technology can provide students with new challenges and ways of demonstrating knowledge. Like many of the participating teachers, George found that utilizing what students do outside of school as springboards to learning created engaging momentum. For instance, George discussed how some young gamers used how-to videos (such as PSAs, or public announcements for gamers, and instructional tutorials) to get further along in their virtual games. Since these instructional videos are created by gamers for gamers, it is an example of how people share their knowledge. George believes that:

maybe it is their responsibility to share their knowledge, rather than just play the game. It's an interesting conversation. That's how transformative our technology is that we can do that. I love that idea that anyone can contribute. There's research, critical thinking, and writing involved and these are important skills to learn. 
This is indeed an interesting conversation of authorship, both in and out of the classroom. Furthermore, everything George did in his classroom was housed "with wide open access", made possible through his classroom Moodle, a Virtual Learning Environment (VLE). George found that his students were engaged:

It was something that meant they were elaborating, working together, sharing ideas, exploring information, and coming together, rather than recreating worksheets. The Moodle was key for that different integration, different ways for the kids to collaborate, share their work, and become much more of a community.

As these teachers have uncovered, writing for a purpose, sharing knowledge, and often authorship, while learning academic and social skills have taken on new possibilities with digital technologies.

Sheba taught the writing process by providing space for collaborative writing and sharing. By using a fractured fairytales activity, Sheba shared traditional fairytales often told from another character's perspective in order to convey different meanings or more modern messages. Sheba first read a few fractured fairytales to the students and together they discussed what makes a fairytale and how the stories could be adapted. During writing periods, Sheba's students utilized writing journals, often with pen and paper while a few students used writing programs on the classroom computers. "It's all about getting your ideas out there," said Sheba. "So we use the writing journals to write, and if they want to keep working on one story for a while that's fine too." It was a tool they often used and a place where they could "write and then share with each other." The students also talked about the stories in order to give each other constructive feedback:

We talk about each of the stories. They talk about what they thought about the story. Sometimes they say, 'you used then a lot'. So then the student can change that. The kids talk about how funny stories are. They are very supportive of each other. They know how it feels. So then they go back and work on it again.

Leela also discussed how one of their students finally described himself "as a writer". She said, "He likes it when people ask him about his writing. It's a big deal to him. And we can see the progression of what and how he has written online overtime. He writes with confidence and he's okay with others reading what he's written." The teachers found that it's the process of writing that is important; the process of the writing, the peer feedback, the publishing, or not, and the continuing practice of writing to share with others.

Developing authorship was how Ria taught essay writing. Ria shared how her students "hated writing in traditional forms." So, she tried various means of having her students understand what encompassed a thesis, and eventually attempted spoken word essays. Ria said, "We watched a bunch of spoken word performances and dissected them to find the thesis and the supporting points. They thought the traditional writing was boring, so I changed it up." When Ria presented a different way of tackling essay writing with her grade 8 students, she found that they wrote all the time, just as "they rhymed and rapped, but they still did the thesis and points for their piece." Ria realized the positive impact of this learning opportunity when she discovered that "one girl was writing pieces every night. She wrote one about money and how it affects our world, another about body 
image, and another on family. It was amazing!" Ria found that it was most important to "just make your work engaging for everybody!", a sentiment that emerged as a mantra for these teachers as they planned and enacted the curriculum in their classrooms.

Dona, a grade 8 teacher in a rural school, described how her teaching and curriculum planning continually changes in order to engage her students through meaningful learning opportunities, most notably through digital technologies. Dona was teaching paragraph writing and decided to incorporate social media and the trend of popular food trucks. Dona noted that this is "an example of how my teaching has evolved. Those food trucks are a trend right now. I feel like you have to go with what's current." Dona had done all the preliminary work by contacting food truck owners via social media "and asked if the owners would be okay with my students contacting them about their business. They all responded and agreed to help." Next, as Dona explained, she asked her students to research the food truck industry and contact, from the approved list, food truck owners through Facebook and Twitter. Dona noted:

the students were actually interacting and talking to real people who owned and ran food trucks or who were in the midst of setting up these businesses... And then based on their research, talking to the owners, and using their paragraph knowledge, they had to make their own concept for a truck.

Dona wanted her students to create non-digital posters for their own food trucks, and while she thought the food truck posters might "look a little 'old school' up there on the wall," the way Dona's students obtained their information was through technology. Dona was proud of how her students communicated through social media avenues about an authentic topic. Dona commented on a few of the final products and incorporating current trends into the curriculum:

The calzone one is really a good one; the paragraphs are long, too. The truck is called Cal's Zone, which I think is clever. And another good one is Crazy Stream: her paragraphs are a little weaker but the idea was cool. The student saw it on Pinterest about making spaghetti by putting it into Ziplock bags and adding food colouring and water.

Dona also noted that home-to-school connections grew out of this activity: "Now the students and their families are starting to visit the ones we talked with in class. Every week a kid comes in with a picture of a truck that they ate at, which is fun." Through this literacy activity, which linked digital technologies and relevant learning possibilities, Dona also found that more emerged from the connections her students made with the food truck owners:

It's good to learn to be an entrepreneur and how different people have taken different paths to make a living. All these people said that they are really driven and motivated. Sometimes school is challenging for kids, but they can always be successful at something. 
Finding connections and building successful learning opportunities and creative, openaccess learning spaces were key components for these teachers. These participating teachers championed the potential for learning and teaching with digital tools and resources, sharing how they found, planned, and frequently utilized digital literacy tools to drive their writing curriculum and engage their students.

\section{Implications and Conclusion}

Co-teaching grades 5 and 6 for a number of years together, Daphne and Leela had many stories about when they knew what they were doing in their classrooms was actually working. Daphne shared that their students wrote purposefully everyday "on things that mean something to them" and they were exposed to a wide variety of writing examples. Daphne and Leela also had the opportunity to teach most of their students over a two-year period. Daphne said:

They are better writers! Based on our students' work and what the students say in their end of the year survey. They felt they had more opportunities to practice writing, and, therefore, that they were better writers. And, you can really see it with the students we've had with us for two years.

A proponent for engaging authorship, Daphne "found the more opportunities the students have for writing, the more they're being aware of themselves as a writer." Daphne and Leela, and all the participating teachers in this study, continually search for those engaging opportunities.

But, there are challenges when incorporating digital technologies into classrooms. While the teachers, at various degrees of integration, wanted to encompass a variety of digital resources into their curriculum and digital tools into their classroom, there were challenges to implementation. Issues of access and constraints were experienced by the teachers as functionality of the classroom hardware and software were a concern. While Ted claimed to be able to "work around" any issue, Claire shared how "technology is great until it doesn't work." Or, as Cassidy noted, "technology is an equity issue. Some kids can go home and bring back pages of research, while some kids have to use the school or local library, or limited classroom computers." When Roxanne moved into a grade 3 class she realized how political obtaining technology had become when, during an EQAO year, she "was given everything I asked for, and access to more." Cassidy was also frustrated because she was trying to obtain technology "to do more innovative teaching and learning but realized that there was a barrier because I didn't have certain things in place already." Some teachers were able to circumvent these issues, such as encouraging Bring Your Own Devices to school and leveraging the community for digital resources, but these were not always options for the teachers. Perhaps these inequities are, as George explained, forcing us "into a different way of thinking" about access of resources.

Finally, there remains a continual need to study practical curriculum-based literacy pedagogy, particularly that of ever-changing digital technologies usage in the classroom in relation to writing instruction and engagement. Drawing on Merchant's (2008) continuum of how teachers infuse curriculum with digital writing, the participating teachers varied in how they implemented technology in their teaching. 
While some of their approaches to teaching writing digitally sequentially introduced existing writing pedagogical approaches and technology access, most teachers created opportunities for their students, and themselves, to utilize digital tools and increase everyone's access. In fact, situated at the far end of the spectrum, most participating teachers infused their literacy curriculum with new digital writing approaches. They invested in new hardware and software and provided constant access for their students. These teachers accessed "new approaches based on a changed view of literacy and the possibilities of new technology" (Merchant, 2008, p. 758). By researching what participating elementary teachers perceive in regards to new literacies teaching, this study can extend the literature on what encompasses being a literacy teacher, how these teachers perceive their multimodal writing pedagogy engages their students, and the resources that have been explored in relation to new literacies teaching.

As we continually re-consider literacies and literacy pedagogy, the teachers in this study continually re-style their curriculum designs and rework their pedagogy to find new ways into teaching and learning. Through the theoretical lens of New Literacies, the work of these teachers supported the four assumptions: digital technologies present new possibilities to literacy tasks, equity to digital technologies can require explicit teaching, change is essential to technologies and literacies, and new literacies are multimodal. The planning and teaching done by these teachers, through utilizing social networking sites, designing media projects with video applications, using media to springboard into critical media projects, and integrating virtual learning environments daily into the classroom, all contribute to the discussion of new literacies in classrooms. But, questions remain. Here, I consider Rowsell's (2016) conversations with global scholars on digital literacies, the connection between digital technologies and literacies. Rowsell states that "digital literacies are many things all at once - highly visible, globally dispersed, differentially proportioned, socially participatory - not to mention that they make us think in a multitude of ways" (p. 121). This thinking in a multitude of ways encourages us to continue delving deeper into this conversation on digital technologies in the classroom, and how these new literacies are finding their way into the dialogue of teachers' planning and enactment of curricula.

\section{References}

Barone, D. \& Wright, T. E. (2008). Literacy instruction with digital and media technologies. The Reading Teacher, 62(4), 292-302.

Bomer, R., Zoch, M. P., David, A. D., \& Ok, H. (2010). New literacies in the material world. Language Arts, 88(1), 9-20.

Charmaz, K. (2005). Grounded theory in the 21st century: Applications for advancing social justice studies. In N. K. Denzin \& Y. S. Lincoln (Eds.), The SAGE handbook of qualitative research (3rd ed., pp. 507-531). Thousand Oaks, CA: SAGE Pub.

Coiro, J., Knobel, M., Lankshear, C., \& Leu, D. J. (2008). Central issues in new literacies and new literacies research. In J. Coiro, M. Knobel, C. Lankshear, \& D. J. Leu (Eds.), The handbook of research in new literacies (pp. 1-21). NY: Lawrence Erlbaum Assoc. 
Cope, B. \& Kalantzis, M. (2009). Multiliteracies: New literacies, new learning. Pedagogies: An International Journal, 4(3), 164-195. doi: 10.1080/15544800903076044

Cook, M. \& Kirchoff, J. (2017). Teaching multimodal literacy through reading and writing graphic novels. Language \& Literacy, 19(4), 76-95. Retrieved from https://journals.library.ualberta.ca/langandlit/index.php/langandlit/article/view/28 645

Corbin, J. \& Strauss, A. (2008). Basics of qualitative research: Techniques and procedures for developing grounded theory ( $3^{\text {rd }}$ ed.). Thousand Oaks, CA: SAGE Pub.

Creswell, J. W. (2007). Qualitative inquiry and research design: Choosing among five traditions $\left(2^{\text {nd }}\right.$ ed.). Thousand Oaks, CA: SAGE Pub.

Denzin, N. K. \& Lincoln, Y. S. (2005). Introduction: The discipline and practice of qualitative research. In N. K. Denzin \& Y. S. Lincoln (Eds.), The SAGE handbook of qualitative research (3rd ed., pp. 1-29). Thousand Oaks, CA: SAGE Pub.

Edwards-Groves, C. J. (2011). The multimodal writing process: Changing practise in contemporary classrooms. Language and Education, 25(1), 49-64. doi:10.1080/09500782.2010.523468

Edwards-Groves, C. (2012). Interactive creative technologies: Changing learning practices and pedagogies in the writing classroom. Australian Journal of Language and Literacy, 35(1), 99-113. Retrieved from http://www.alea.edu.au/documents/item/348

Fantozzi, V. B., Johnson, C. \& Scherfen, A. (2017). One classroom, one iPad, many stories. The Reading Teacher, 71(6), 681-689. doi:10.1002/trtr.1651

Glaser, B.G. \& Straus, A. L. (1967). The discovery of grounded theory: Strategies for qualitative research. NY: Aldine de Gruyter.

Graham, M.S. \& Benson, S. (2010). A springboard rather than a bridge: Diving into multimodal literacy. English Journal, 100(2), 93-97. Retrieved from http://www.ncte.org/library/NCTEFiles/Resources/Journals/EJ/1002nov2010/EJ1002Spring.pdf

Hull, G. \& Schultz, K. (2002). Connecting schools with out-of-school worlds. In G. Hull \& K. Schultz (Eds.), School's out!: Bridging out-of-school literacies with classroom practice (pp. 32-57). NY: Teachers College Press.

Hull, G. A. \& Katz, M. L. (2006). Crafting an agentive self: Case studies of digital storytelling. Research in the Teaching of English, 41(1), 43-81.

Hutchison, A., Beschorner, B., \& Schmidt-Crawford, D. (2012). Exploring the use of the iPad for literacy learning. The Reading Teacher, 66(1), 15-23.

Janks, H. (2010). Literacy and power. New York: Routledge.

Jewitt, C. (2005). Multimodality, "reading", and "writing" for the $21^{\text {st }}$ century. Discourse: Studies in the Cultural Politics of Education, 26(3), 315-331.

Karchmer-Klein, R. \& Shinas, V. H. (2012). Guiding principles for supporting new literacies in your classroom. The Reading Teacher, 65(5), 288-293.

Kendall, L. (2008). The conduct of qualitative interviews: Research questions, methodological issues, and researching online. In J. Coiro, M. Knobel, C. Lankshear \& D. J. Leu (Eds.), The handbook of research in new literacies (pp. 133-149). NY: Lawrence Erlbaum 
Assoc.

Kist, W., Doyle, K., Hayes, J., Horwitz, J. \& Kuzior, J.T. (2010). Web 2.0 in the elementary classroom: Portraits of possibilities. Language Arts, 88(1), 62-68. Retrieved from http://www.ncte.org/library/NCTEFiles/Resources/Journals/LA/0881sep2010/LA0881Profiles.pdf

Knobel, M. \& Lankshear, C. (2007). Sampling "the new" in new literacies. In M. Knobel \& C. Lankshear (Eds.), A new literacies sampler (pp. 1-24). NY: Peter Lang.

Kress, G. (1997). Before writing. NY: Routledge.

Lapp, D., Moss, B., \& Rowsell, J. (2012). Envisioning new literacies through a lens of teaching and learning. The Reading Teacher, 65(6), 367-377.

Lenters, K. (2014). Just doing our jobs: A case study of literacy-in-action in a fifth grade literature circle. Language and Literacy, 16(1), 53-70.

Leu, D. J., Kinzer, C. K., Coiro, J., Castek, J., \& Henry, L. A. (2013). New literacies: A dual level theory of the changing nature of literacy, instruction, and assessment. In D. E. Alvermann, N. J. Unrau \& R. B. Ruddell (Eds.), Theoretical models and processes of reading, ( $6^{\text {th }}$ ed., pp. 1150-1181). Retrieved from https://www.researchgate.net/publication/278914723_New_Literacies_A_DualLevel_Theory_of the_Changing_Nature_of_Literacy_Instruction_and_Assessme $\underline{\mathrm{nt}}$

Martens, P., Martens, R., Doyle, M. H., Loomis, J., \& Aghalarov, S. (2012). Learning from picturebooks: Reading and writing multimodally in first grade. The Reading Teacher, 66(4), 285-294.

McClenaghan, M. (2013). They call me Mr. MOODLE: How I used my virtual learning environment to increase the motivation in my writer's workshop: A self-study.

Journal of Classroom Research in Literacy, 6, 3-13.

Merchant, G. (2008). Digital writing in the early years. In J. Coiro, M. Knobel, C. Lankshear \& D. J. Leu (Eds.), The handbook of research in new literacies (pp. 751-774). NY: Lawrence Erlbaum Assoc.

Mills, K.A. (2010). Shrek meets Vygotsky: Rethinking adolescents' multimodal literacy practices in school. Journal of Adolescent and Adult Literacy, 54(1), 35-45.

Rowling, J.K. (2000). Harry Potter and the philosopher's stone. Vancouver: Raincoast Books.

Rowsell, J. (2016). Humanizing digital literacies: A road trip in search of wisdom and insight. The Reading Teacher, 70(1), 121-129.

Schultz, K. (2006). Qualitative research on writing. In C. A. MacArthur, S, Graham \& J, Fitzgerald (Eds.), Handbook of writing research (pp. 357-373). NY: Guildford Press.

Shelby-Caffey, C. Úbéda, E. \& Jenkins, B. (2014). Digital storytelling revisited: An educator's use of innovative literacy practice. The Reading Teacher, 68(3), 191199.

Smith, C.R. (2000). Rimshots: Basketball pix, rolls, and rhythms. NY: Puffin Books. Spinelli, J. (1997). Crash. NY: Yearling Books.

The New London Group. (1996). A pedagogy of multiliteracies: Designing social futures. Harvard Educational Review, 66(1), 60-92. Retrieved from 
https://www.hepg.org/her-home/issues/harvard-educational-review-volume-66issue-1/herarticle/designing-social-futures 290

The New London Group. (2000). A pedagogy of multiliteracies: Designing social futures. In B. Cope \& M. Kalantzis (Eds.), Multiliteracies: Literacy learning and the design of social futures (pp. 9-37). London: Routledge.

Ware, P. D. (2006). From sharing time to showtime! Valuing diverse venues for storytelling in technology-rich classrooms. Language Arts, 84(1), 45-54.

Willems, M. (2003). Don't let the pigeon drive the bus! NY: Hyperion Books for Children.

\section{Author Biography}

Carol Doyle-Jones, $\mathrm{PhD}$, is an Assistant Professor in the Ontario Programs Department, College of Education at Niagara University. Her research centers on understanding what it means to be an educator in the $21^{\text {st }}$ century, with a focus on teacher collaboration, multimodal texts and designs, and our culturally diverse classrooms. 